\title{
Decreasing the surface run-off through the rainfall absorption in Bandung Basin
}

\begin{abstract}
Expansion of built-up area was increasing the surface run-off. This research conducted in Bandung basin and aims to analyzing land use change, volume of rainfall that was not absorbed by built-up area and the attempts to decrease surface run-off volume in the built-up area. Method that used is spatial analysis. The formula calculates the volume of rain: $\mathrm{Ih}=\mathrm{LxK}$, and to measures the volume of rainfall: $\mathrm{V}=\mathrm{RxA}$. The built-up area changes from $458,507,000 \mathrm{~m}^{2}$ to $535,155,000 \mathrm{~m}^{2}$. The results depict built-up area change from $458,507,000 \mathrm{~m}^{2}$ to $535,155,000 \mathrm{~m}^{2}$. The built-up area expansion affected the increase in surface run-off from the average volume of $34,250,473 \mathrm{~m}^{3}$ to $39,079,976 \mathrm{~m}^{3}$. The way to decrease the volume of flooding which continously increased is by absorbing the volume of rainfall in each built-up area of every $100 \mathrm{~m}^{2}$. The highest rainfall volume in December has been up to $1,100 \mathrm{~m} 3$ in order that each built-up area of $100 \mathrm{~m}^{2}$ have to absorb rainfall of $1,100 \mathrm{~m}^{3}$ in the infiltration wells. Because the built-up area is different, it is calculated from the thickness of the rainfall multiplied by large, then the volume of rainfall must be absorbed. By storing and absorbing the rainfall in each built-up area, the surface run-off could be avoided in the area of Bandung basin.
\end{abstract}

Keywords: geography, surface, run-off, rainfall, absorption, bandung, basin, flooding, land-use changes, agriculture, forests, and plantations
Volume 3 Issue 6 - 2019

\author{
Dede Sugandi,' Ramadhan Pascawijaya² \\ 'Department of Geography Education, Universitas Pendidikan \\ Indonesia, Indonesia \\ 2Mapping Survey and Geography Information, Universitas \\ Pendidikan Indonesia, Indonesia
}

Correspondence: Dede Sugandi, Department of Geography Education, Universitas Pendidikan Indonesia, Indonesia, Email dedesgandi@upi.edu

Received: November 28, 2019 | Published: December 24, 2019

\section{Introduction}

One of the implications of population concentration is changes in land function, such as from agricultural lands to non-agricultural lands or from non-agricultural lands to another non-agricultural land use. Limited lands and the dynamics of the urban community's activities cause competition in land uses and land-use changes. ${ }^{1}$ The concentration of population has demanded to build various facilities such as housing, social and public facilities. The existing land is indispensable side to construct facilities as changing the land use from agriculture, forests, and plantations to residential land and public and social facilities. ${ }^{2,3}$ As a consequence, the conversion of land use to meet life needs influences land surface characteristics of flow. ${ }^{4,5}$ The land-use changes play an essential role in the water balance changes in Goseng catchment, indicated by increasing surface run-off along with the decline of vegetation cover. ${ }^{6}$

However, population growth and migration in limited land encourage people to live in disaster-prone areas. ${ }^{7.8}$ The environment can be defined as the surroundings in which an entity operates. It includes air, water, land, natural resources, flora, fauna, humans and their interrelation. ${ }^{9}$ Changes in land use and land cover are significant in global climate Change. ${ }^{10}$ The Kelani River watershed includes $23 \%$ of the total urban area of the Colombo district. Similarly, the entire area of land-use transformation covered $37.7 \%$ of the area within the watershed region of the Colombo district. Eventually, this research identified the significant impact of Colombo district floods in May 2016 on land-use changes. ${ }^{11}$

The impact of the population's concentration is an obstacle in gaining the standard of sustainable life quality because it affects environmental quality. The urbanization has led to severe environmental problems in ZJP, not only on the city scale but also on the regional scale. Maintaining a balance between the continuing process of urbanization and environmental sustainability is a significant issue facing the local government. ${ }^{12}$ Land-use change is a crucial issue considering global dynamics and their response to hydrologic characteristics of soil and water management in a catchment. ${ }^{13} \mathrm{~A}$ watershed is a hydrologic unit or an area of land from which water drains, running downhill, to a shared destination or which produce water as the end product by the interaction of precipitation and the land surface. ${ }^{14}$

The concentrated population migration would form a pattern of settlements on open land affecting environmental balance. Sustainable development is a pattern of resource use that aims to meet human needs while preserving the environment. ${ }^{15}$ Human beings have to utilize land, causing disturbance to the stability and equilibrium of the environment. ${ }^{16}$ Environmental balance has been in an obstacle to experiencing a sustainable decent life. Sustainable water systems often comprise complex combinations of traditional and new system components that mimic natural processes. ${ }^{17-19}$ Urban run-off pollution is caused when the run-off while travelling across the urban environment, acquires contaminants that affect water quality. ${ }^{20}$ The impact of land uses can cause significant changes in the hydrological regime of a river basin. ${ }^{21}$ The increase in flood peak and a decrease of the rangelands, forests, and bare lands between 1984 and 2011, indicating a good correlation between flooding areas and land-use changes. $^{22}$

Expansion of built-up area such as settlements and commercial buildings shapes a waterproof layer. The peak flow is faster in the watershed area as the potential for flooding. ${ }^{23,24}$ The hydrological conditions upstream of the Ciliwung watershed are changing due to climate and land-use changes. Any changes in this area may increase the flood frequencies, which may have incalculable consequences downstream of the watershed where the Jakarta city is located. ${ }^{25}$

The healthy environment must be kept and maintained because sustainable life is influenced by environmental sustainability. Collaborative conservation strategies for protecting and managing 
natural resources help in creating a healthy eco-system. A collaborative approach gives a chance in which conservation issues are targeted collectively by using adaptive management of whole ecosystems, including human communities. ${ }^{26}$ Settlement on floodplains contributes to flooding disasters by endangering humans and their assets. However, the economic benefits of living on the floodplain outweigh the dangers for some societies. Pressures from population growth and shortages of land also promote settlement on floodplains. ${ }^{27}$ Developing, testing and implementing indicators to identify and assess vulnerability to floods is an essential pre-requisite for effective disaster risk reduction. ${ }^{28}$ Conservation is closely related to the socioeconomy of the inhabitants. If the land is damaged, the sustainability of the resources will decrease, and eventually, this will impact on the sustainability of life and development. ${ }^{29,30}$ The climate change effects in the Sundarbans Mangrove forest through changing its biodiversity composition in terms of loss of wildlife habitats, which is responsible for accelerating tiger human conflicts. ${ }^{31}$ The mentioned statement reveals that the environment supports human life in which humans as environmental components that should be in the use of land always consider environmental balance.

The leading cause of surface run-off increases is due to changes in land use. Urban as a centre of human activity, as well as high population density, will induce urban areas dominated by builtup area. ${ }^{32}$ Run-off corresponding to rainfall and infiltration. In the infiltration (source) areas of PZWR (Protection Zones of Water Resources), the hydrogeological structure undergoes significant water infiltration, while large volumes of groundwater accumulate in the accumulation area. ${ }^{33,34}$ The upstream watershed has developed as a built area so that there is not enough extensive land that can be used as a retention basin. Settlement land with flood area correlates 0.849 , flood height correlates 0.592 , and flood height correlates $0.592 .{ }^{35}$ A review of catchment studies $(n=37)$ conducted in East Africa evaluating the impacts of Land Use and Land Cover Changes (LULCC) on discharge, surface run-off, and low flows. ${ }^{36}$

The built-up area causes increased surface run-off while to reduce it, reducing surface run-off is through conservation. Conservation techniques such as percolation pond, check dam, etc., can be recommended for better management of land and water resources for sustainable development of the watershed ${ }^{37}$ Agricultural and forest monitoring is a valued instrument needed by public authorities (PA) for determining land uses, planning natural resources management and collecting taxes. ${ }^{38}$ To reduce flow discharge, the rainfall must be absorbed into the soil. Jifa ${ }^{39}$ said the implication this development is decreasing of urban open space area by $1-2 \%$ per year, and followed by increased surface run-off during rain. Infiltration well is one of the efficient rainwater utilization to reduce run-off.

The expansion of built-up area gives rise to an increase in surface run-off and flooding so that the tremendous efforts overcome surface run-off and flooding by increasing the absorption. Therefore, this study aims to:

a. Analyzing land use change in Bandung basin by using remote sensing

b. Analyzing the volume of rainfall that was not absorbed by builtup area in Bandung basin

c. Analyzing the attempts to decrease surface run-off volume in the built-up area in Bandung basin

\section{Methods}

The Bandung basin has a bowl-like shape bordered by mountains as the basins seem like small rivers that empty into the upper part of $\mathrm{Ci}$ Tarum located on the plains of Bandung. It covers the area of Bandung City, Cimahi City, Bandung Regency, West Bandung Regency and part of Sumedang Regency. The emergence of Ci Tarum's rivers is located in the plains region, namely, Rancaekek and Dayeukkolot. Changes in land use are by using satellite, namely Landsat 7 imagery in 2010 and Landsat 8 imagery in 2015. Steps in the analysis was preparing Landsat 7 and 8 imagery, interpretation of Landsat 7 and 8 imagery, ground check, adjusting the results of interpretation with ground check. Landsat 7 using band true color 321 (Red Green Blue) and Landsat 8 can be used band 543 (N- Infrared, red, green) to identify vegetation and water surface. The difference lies on the length of spectral range. The second identification of Landsat imagery was conducted by geometric and radiometric correction to harmonize the information of object from the imagery. The research method used is remote sensing by Software Er Mapper consisting of stages as follows: preparation, interpretation, survey, reinterpretation and report. The results of the imagery analysis were carried out the survey by data collection in the field. The analysis techniques were started from (a) cropping (b) sharpening imagery; (c) classification imagery. In the sample area, the volume of rainwater is measured on the built-up area. Volume of surface run-off is calculated from rainfall. Rainfall is calculated from 3 BMKG stations spread over 2 mountain areas and 1 in the city of Bandung. The data is the average of rainfall in 10 years, so the authors take the average of thickness in rainy day and hourly average. This is used to determine the amount of rainfall that must be absorbed in the building area.

$$
R_{h}=\frac{R_{m}}{R_{d}} / 24
$$

$$
\begin{aligned}
& \mathrm{R}_{\mathrm{h}}=\text { rainfall } \mathrm{mm} / \text { hour } \\
& \mathrm{R}_{\mathrm{m}}=\text { rainy day/month } \\
& \mathrm{R}_{\mathrm{d}}=\text { number of days }
\end{aligned}
$$

While the measurement of rainfall volume was evaluated by using the formula, this model is also used to measure the volume of rain that occurs in the smallest unit of the land area of $100 \mathrm{~m}^{2}$, namely:

$$
\begin{aligned}
& \boldsymbol{V}=\mathbf{R} \times \mathbf{A}, \\
& \boldsymbol{V}=\operatorname{volume}\left(\mathrm{m}^{3}\right), \\
& \mathbf{R}=\operatorname{rainfall}(\mathrm{mm}), \\
& \mathbf{A}=\operatorname{area}\left(\mathrm{km}^{2}\right) .
\end{aligned}
$$

\section{Results and discussion}

\section{Changes in land use}

The Bandung is well known as a basin area because the middle of the basin is plain. Activities of population and development are concentrated in the plains region. As the logical consequence to meet the population needs, it causes changes in land use as the alteration of water movement process. The changes are being the built-up area in which rainfall that occurs on the land will become surface run-off. The wider built-up area has encouraged the land unable for absorbing 
rainfall. Land Use and Land Cover Change (LUCC) can reflect the pattern of human land use in a region and plays an essential role in space soil and water conservation. The Bandung basin is an area bordered by mountains, and the middle is plain. In this research, the boundaries of basin land use are by analyzing the Landsat 7 Imagery in 2010 and Landsat 7 imagery in 2015. From the results of the analysis, there are six classes of land use forms. The results of the 2010 Landsat Imagery analysis are shown on the Map which can be seen at Figure 1. The imagery of paddy fields is depicted in the dark blue, regular, square and rectangular with the embankment.

a. Forests are shown in reddish, rough texture, irregular and path.

b. Mixed gardens are shown in pink, rough texture, regular and settlement.

c. Uplands and fields are revealed by bright red mixed, square shape, slightly rough texture, regular patterns and settlement.

d. Shrub and bushes are shown by bright red, rather smooth texture, and irregular patterns.

e. Plantations are shown in pink, regular patterns, and smooth texture of the path.

f. Settlements, offices and industries are shown in white, square and rectangle, uniform size, rough texture, regular pattern, and many roads.
The analysis of imagery is classified into seven forms of land use shown in Map as an analysis of changes in land use form shown in Table 1.

The area of built-up area and moor increases while the reduced area is paddy fields and forests. Changes in built-up area affect the surface as impermeable to increase water.

\section{The volume of surface run-off}

When raining, rainfall on the built-up area becomes surface run-off streaming on the surface of the land and ending in the river. The flow that moves on the built-up area is hampered by various buildings such as sidewalks, settlements and substandard drainage buildings, while the volume of the moving surface run-off increases in the river body, and it overflows as the flow on the surface will be concentrated in the plain causing flooding. The volume of a surface run-off is calculated from the average rainfall of three stations.

July is the time that has the lowest rainfall of around $35 \mathrm{~mm} /$ day, and the highest rainfall occurs in the month of $336 \mathrm{~mm} /$ day, whereas the lowest rainfall in hours happens in January around $0.454 \mathrm{~mm} /$ hour, and the highest occurs in September around $1,067 \mathrm{~mm} /$ hour. Daily rainfall that prevails calculated in units of hours, therefore rainfall is classified into 24hours. The thickness of rainfall in hours is small, but the thickness of rainfall multiplied by area will be a large volume of water (Table 2).

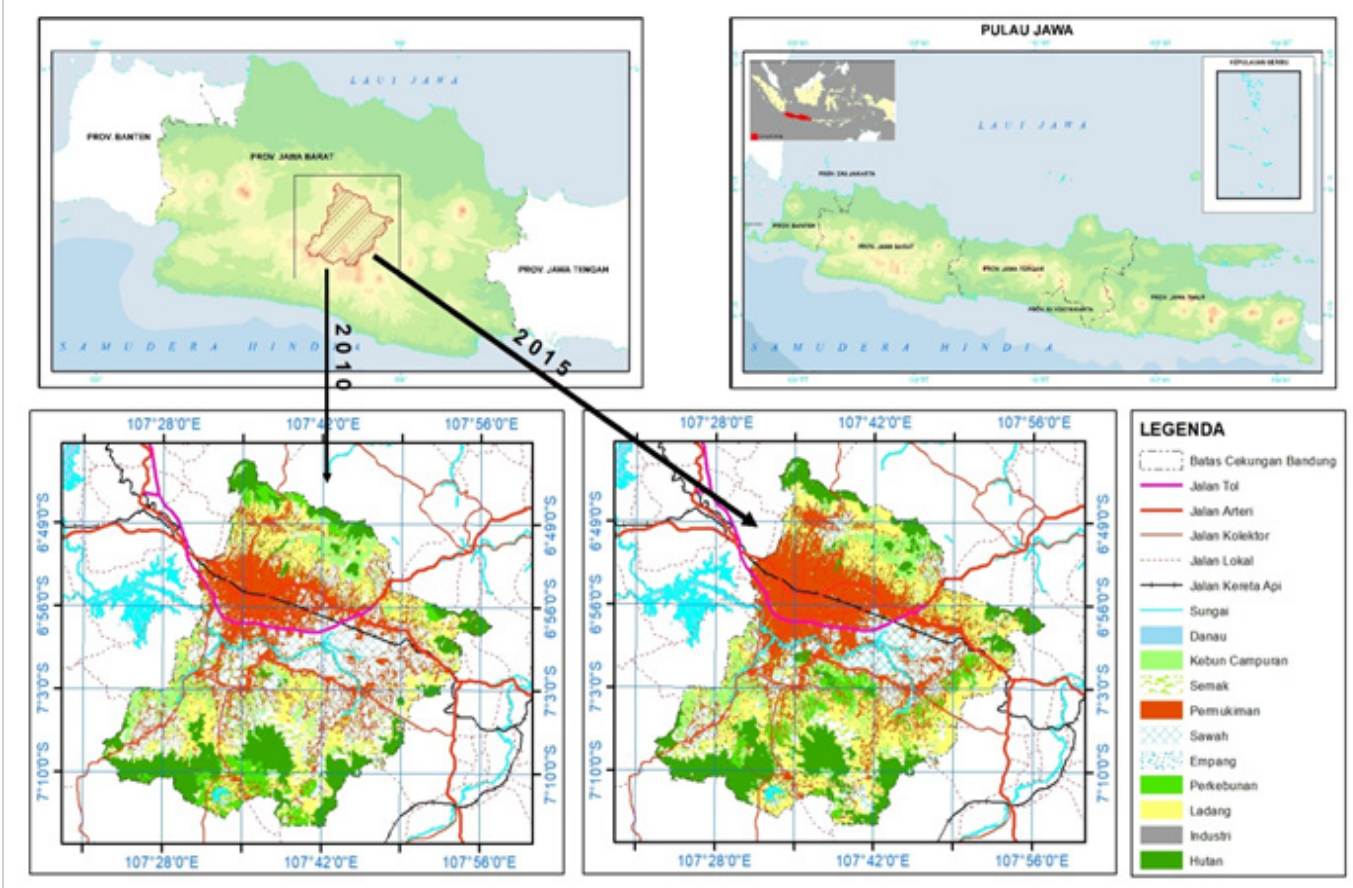

Figure I Land Use Change in 2010 and 2015.

The presented Table 3 shows that the thickness of rainfall is small but multiplied by the area of built-up area into an enormous volume of water. The built-up area in 2010 was $458,507,000 \mathrm{~m}^{2}$, while in 2015 it was $535,155,000 \mathrm{~m}^{3}$. The adverse effect of the change in the land into built-up area is the volume of increased surface run-off that causes flooding. To incline the volume of the flow, the enormous effort to reduce surface run-off by absorbing surface run-off is needed. Increasing the volume of recharge in large volumes requires vast land, costs and energy. Therefore, to increase surface run-off, applying the volume of rainfall falls on each building absorbed into the soil through infiltration wells. This water infiltration model is calculated for each smallest unit of land with $100 \mathrm{~m}^{2}$. 
Table I Comparison of the Land Use Are in 2015

\begin{tabular}{llllll}
\hline \multicolumn{1}{c}{ Year } & & & \\
\hline & & 2010 & 2015 & Change & \\
\hline Landuse & Large $\left(\mathbf{K m}^{2}\right)$ & Large $\left(\mathbf{K m}^{2}\right)$ & Extends & Narrowed \\
\hline 2 & Bush & 458,507 & 535.155 & 76,648 & - \\
3 & Plantation & 121,337 & 129.272 & 7,935 & - \\
4 & Mixed garden & 82,681 & 85.58 & 2,899 & - \\
5 & Forest & 182,685 & 182.489 & - & 196,000 \\
6 & Moor & 265,927 & 269.243 & - & 16,684 \\
7 & Paddy field & 282,569 & 395.448 & 112,879 & - \\
& Total & 517,791 & 334.31 & - & 183,481 \\
\hline
\end{tabular}

Table 2 Monthly average rainfall $(\mathrm{mm})$ in 2006-20I5

\begin{tabular}{|c|c|c|c|c|c|c|c|c|c|c|c|c|}
\hline Station & Jan & Feb & Mar & Apr & May & Jun & Jul & Aug & Sep & Oct & Nov & Des \\
\hline Lembang & 142.1 & 221.9 & 201.8 & 204.1 & 178.5 & 62.2 & 62 & 26.9 & 60.8 & 104.5 & 299 & 262.3 \\
\hline Cisondari & |42.| & 170.2 & 158.6 & $|5|$ & 152.6 & 50.7 & 26.2 & 22.4 & 40.2 & 76.3 & 168.4 & 192.3 \\
\hline Cileunca & $24 I$ & 268.7 & 266.8 & 265 & 133.8 & 57.9 & 35 & 37 & 52.7 & 118.2 & 292 & 336.9 \\
\hline Rainfall & I75.I & 220.2 & 209.1 & 206.7 & 155 & 56.9 & 41.1 & 28.8 & 51.2 & 99.7 & 253.1 & 263.8 \\
\hline Day/rain & 16 & 16 & 15 & 16 & 7 & 3 & 2 & 2 & 2 & 4 & 13 & 15 \\
\hline Rain/day & 10.9 & 13.8 & 13.9 & 12.9 & 22.1 & 19 & 20.5 & 14.4 & 25.6 & 24.9 & 19.5 & 17.6 \\
\hline Rain/hour & 0,454 & 0,575 & 0,579 & 0,538 & 0,921 & 0,792 & 0,854 & 0,600 & 1,067 & 1,038 & 0,813 & 0,733 \\
\hline
\end{tabular}

Source: Dinas PU Pengairan, 2016

Table 3 Volumes of Surface run-off in the Bandung Basin

\begin{tabular}{|c|c|c|c|c|c|}
\hline Month & Rainfall (mm/hour) & $\begin{array}{l}\text { Built Land }\left(100 \mathrm{~m}^{2}\right) \\
2010\end{array}$ & Volume $\left(\mathrm{m}^{3}\right)$ & Built-up area $\left(100 \mathrm{~m}^{2}\right) 2015$ & Volume $\left(\mathrm{m}^{3}\right)$ \\
\hline January & 0,454 & & 20.816 .218 & & 24.296 .037 \\
\hline February & 0,575 & & 26.364 .153 & & $30.77 \mid .413$ \\
\hline March & 0,579 & & 26.547 .555 & & 30.985 .475 \\
\hline April & 0,538 & & 24.667 .677 & & 28.791 .339 \\
\hline May & 0,921 & & 42.228 .495 & & 49.287 .776 \\
\hline June & 0,792 & & 36.313 .754 & & 42.384 .276 \\
\hline July & 0,854 & 4.585 .070 .000 & 39.156 .498 & 5.351 .550 .000 & 45.702 .237 \\
\hline August & 0,600 & & 27.510 .420 & & 32.109 .300 \\
\hline September & I,067 & & 48.922 .697 & & 57.101 .039 \\
\hline October & 1,038 & & 47.593 .027 & & 55.549 .089 \\
\hline November & 0,813 & & 37.276 .619 & & 43.508 .102 \\
\hline December & 0,733 & & 33.608 .563 & & 39.226 .862 \\
\hline Total & & & 411.005 .676 & & 479.712 .945 \\
\hline Average & & & 34.250 .473 & & 39.079 .976 \\
\hline
\end{tabular}




\section{Increased Infiltration}

The volume of flowing rainfall built-up area needs to be absorbed into the soil based on the volume of rainfall in the smallest unit. As built-up area is in a different large, thickness of rainfall that falls on a building multiplied by its land area then obtained by rainfall volume. For more accessible, the smallest unit model of a building $100 \mathrm{~m} 2$ is required to construct. With this volume, it will be easy to calculate the water that needs to be absorbed. The volume of flow inland units per $100 \mathrm{~m}^{2}$ with the duration of rain in 5 and 10hours is shown in Table 4. The constructed land model of the entire area is divided into the smallest unit of land area per $100 \mathrm{~m}^{2}$ so that there are $5,351,550,000$ with the volume of water/hour/day. Rainfall often occurs, especially the rainy season and the frequency of rain in a month as many as 16days. The duration of rain in a day can reach more than 10 hours. This study uses old rain models about 5 and 10hours, in order that an illustration of the water volume falling on the built-up area in the smallest unit of $100 \mathrm{~m}^{3}$ can be calculated.

The given Table 4 shows the rainiest days occur from November to April with the highest volume of water at $0.01067 \mathrm{~m}^{3}$. If the assumed duration of rain by 5 and 10 hours, it can be known that the volume of water must be absorbed into the soil. The volume of water from a land unit of $100 \mathrm{~m}^{2}$ has a different volume, and the largest is $1,100 \mathrm{~m}^{3}$. The rainfall that falls on each built-up area is entering the infiltration wells, so it did not become the surface run-off. Rainfall on land cover whose water will be stored in infiltration wells, including parking lots, roof area, and pavement roads, buildings and others. This infiltration wells are effective for collecting and absorbing rainfall.

\section{Discussion}

The expansion of built-up area occurred in the Bandung basin had been analyzed from the 2010 Landsat 7 imagery and 2015 Landsat 8 imagery, showing there are seven classes of land use forms. Changes in land use from ricefields, forests, other agriculture to settlements, industries, or other buildings have affected the surface layer of the land. The soil surface that functions to absorb rainfall turns into a waterproof layer so that rainfall drops to the surface to be impermeable. By analyzing the 2010 Landsat 7 Imagery and the 2015 Landsat 7 imagery, there are seven classes of land use forms. The expansion of land usage form occurs in settlements and industries around $76,648 \mathrm{Km}^{2}$. Hence, changes in land use affect the volume of surface run-off, especially built-up area. The built-up area spreads across the plain and estuary of the tributary to Ci Tarum. Subsequently, changes to built-up area cause increased surface run-off.

The expansion of built-up area was from $458,507 \mathrm{~km}^{2}$ in 2010 to $535,155 \mathrm{~km}^{2}$ in 2015 . The built-up area caused surface run-off rising to $57,101,039 \mathrm{~m}^{3}$ in September. This surface run-off is originally from the built area and is concentrated in the plains region, namely Dayeuhkolot, Majalaya and Rancaekek. The concentration of surface run-off that makes the area experience flooding every year. The volume of surface run-off causes flooding. In order to address it, reducing surface run-off is by absorbing the rainfall on the built-up area in the smallest unit of land $100 \mathrm{~m}^{2}$. By absorbing rainfall in each built-up area, then there is no rainfall into a surface run-off. The smallest unit of the land considered representative in each area of $100 \mathrm{~m}^{2}$. It means each unit of land must absorb the volume of rainfall so that no rainfall becomes the surface run-off.

The volume of rainfall that drops on each of the smallest land units at least $100 \mathrm{~m}^{2}$ permeates the water volume of $1,100 \mathrm{~m}^{3}$ in December, with 10hours of rain. To absorb rainfall in the smallest unit, making infiltration wells that can accommodate $1,100 \mathrm{~m}^{2}$ of water is needed. With the infiltration wells made on each built land $100 \mathrm{~m}^{2}$, the rainfall on the built-up area will not become surface run-off. If applied to all the built-up area, the rainfall that falls on the built-up area would not be the surface run-off.

\section{Conclusion}

Analysis of Landsat imagery in 2010 and 2015 reveals a change in land use, especially the land expansion of $535,155 \mathrm{~km}^{2}$ $\left(535,155,000,000 \mathrm{~m}^{2}\right)$. The built-up area has a water-resistant nature so that the falling rainfall cannot absorb. The waterproof layer causes an increase in surface run-off. In 2015, the expansion of built-up area resulted in an increase in average surface run-off volume from $34,250,473 \mathrm{~m}^{3}$ in 2010 to $39,079,976 \mathrm{~m}^{3}$ in 2015 . The highest volume of rainfall occurs in December, in order that the volume must be absorbed. With infiltration wells in each of the smallest built-up area units, rainfall does not have the potential to be surface run-off that causes flooding. Making retention ponds requires a large area, because to accommodate a very large volume. The built-up area was $535,155,000,000 \mathrm{~m}^{3}$ used as the smallest unit to be $5,351,550,000 \mathrm{~m}^{3}$. By the volume of rainfall having a potential as a surface run-off, it must be absorbed through infiltration wells able to permeate $1,100 \mathrm{~m}^{3}$ on the built-up area of $100 \mathrm{~m}^{2}$. The rainfall would not be the surface run-off by storing and absorbing them in the infiltration wells.

\section{Acknowledgments}

None.

\section{Conflicts of interest}

The authors declares that there is no conflict of interest.

\section{Funding}

None.

\section{References}

1. Adibah N, Kahar S, Sasmito B. Application of Remote Sensing and Geographic Information Systems for Analysis of Watersheds (Case Study: Pekalongan City). Jurnal Geodesi Undip. 2013;2(2):141-153.

2. Saptono P, Rahma H. The Impact of Settlement Development on the Expansion of Inundation Floods in Semarang City. Jurnal Geografi UNNES. 2007;4(1):35-43.

3. Mangeswuri DR, Paramita PN. Development of Housing Availability and Needs in Batam. Jurnal Ekonomi dan Kebijakan Publik. 2012;3(2):409-417.

4. Bhaduri B, Harbor J, Engel B, et al. Assessing watershed-scale, longterm hydrologic impacts of land-use change using a GIS-NPS model. Environmental management. 2000;26(6):643-658.

5. Enger EE, Smith BF, Bockarie AT. Environment Science: A Study of Interrelationship. $10^{\text {th }}$ edition, New York: Mc Graw Hill International Edition. 2006.

6. Nugroho P, Marsono D, Sudira P, et al. Impact of land-use changes on water balance. The 3rd International Conference on Sustainable Future for Human Security Sustain. 2012;17:256-262.

7. Katherina LK. Dynamic of Population Growth and Flooding Incidents in Cities: Case of Surabaya. Journal Kependudukan Indonesia. 2017;1(2):131-144. 
8. Prakash CR, Asra M, Venkatesh J, et al. Monitoring Urban Land-Cover Features using Resourcesat LISS-III Data. International Journal of Advanced Remote Sensing and GIS. 2015;4(1):1064-1069.

9. Sawant VR. Integrated Flood Management in Urban Flooding. International Journal of Research and Development-A Management Review. 2013;2(2):13-16.

10. Goldewijk KK, Dekker SC, Zanden JL. Per-capita estimations of longterm historical land use and the consequences for global change research. Journal of Land Use Science Taylor 7 \& Francis. 2017;12(5):313-337.

11. Dammalage TL, Jayasinghe NT. Land-Use Change and Its Impact on Urban Flooding: A Case Study on Colombo District Flood on May 2016. Engineering, Technology \& Applied Science Research. 2019;9(2):3887-3891

12. Yang $\mathrm{X}$, Yue $\mathrm{W}, \mathrm{Xu} \mathrm{H}$, et al. Environmental Consequences of Rapid Urbanization in Zhejiang Province, East China. International Journal of Environmental Research and Public Health. 2014;11(7):7045-7059.

13. Welde K, Gebremariam B. Effect of land use land cover dynamics on hydrological response ofwatershed: Case study of Tekeze Dam watershed, northern Ethiopia. Journal of International Soil and Water Conservation Research. 2017;5(1):1-16.

14. Jain SK, Tyagi J, Singh V. Simulation of Run-off and Sediment Yield for a Himalayan Watershed Using SWAT model. Journal of Water Resource and Protection. 2010;2(3):276-281.

15. Sefouhi L, Kalla M, Aouragh L. Trends and Problems of Municipa Solid Waste Management in Batna City and Prospects for a Sustainable Development. International Journal of Sustainable Water \& Environmental Systems. 2010;1(1):15-20.

16. Iskandar D, Sugandi D. Flood Mitigation Efforts In The Special Capital Region Of Jakarta. International Journal Of Conservation Science. 2015;6(4):685-696.

17. Sukojo BM. Penggunaan Metode Analisa Ekologi dan Penginderaan Jauh Untuk Pembangunan System Informasi Geografis Ekosistem Pantai. Jurnal MAKARA, Sains. 2003;7(1):32-37.

18. Scholz M. Sustainable Water Systems. Journal of Water 2013;5(1):239-242.

19. Gogate NG, Rawal PM. Identification of Potential Stormwater Recharge Zones in Dense Urban, Context: A Case Study from Pune city. International Journal of Environment Resources. 2015;9(4):1259-1268.

20. Waters S, Farrell-Poe K, Wagner K. When it Rains it Runs Off: Run-off and Urbanized Areas in Arizona. Arizona Cooperative Extension. The University of Arizona. 2011;1-5.

21. A1-Mamun A, Salleh MN, Nuruzzama M, et al. Impact of Imprope Landuse Changes On Flash Flood and River System-A Case Of $\mathrm{Sg}$ Pusu. ARPN Journal of Engineering and Applied Sciences. 2016;11(8):5373-5379.

22. Apollonio C, Balacco G, Novelli A, et al. Land Use Change Impact on Flooding Areas: The Case Study of Cervaro Basin (Italy). Journal of Sustainability MDPI. 2016;8:3-18.

23. Koyari E, Priyantoro, Sisinggih D. Pola Pengendalian Banjir Kawasan Bambu Kuning Kota Jayapura. Jurnal Teknik Pengairan. 2012;3(2):240 249.
24. Weng Q. Modeling Urban Growth Effects on Surface Run-off with the Integration of Remote Sensing and GIS. Journal of Environmental Management. 2001;28(6):737-748.

25. Emam AR, Mishra BK, Kumar P, et al. Impact Assessment of Climate and Land-Use Changes on Flooding Behavior in the Upper Ciliwung River, Jakarta, Indonesia. Journal of Water MDPI. 2016;8:2-10.

26. Singh M, Sinha AK, Singh P. Maintaining The Biodiversity of Informal Protected Areas: A Collaborative Conservational Approach. International Journal Of Conservation Science. 2014;5(1):107-116.

27. Prasad SV. Community Based Disaster Preparedness: A Guide For Development Workers On Cyclones And Floods, India. 2002.

28. Sanayanbi H, Zaphu VV, Monica N, et al. Vulnerability Assessment of Arunachal Pradesh to Floods. International Journal of Innovative Research in Science, Engineering and Technology. 2014;3(4):81-92.

29. Klijn F, Kreibich H, De Moel H, et al. Adaptive flood risk management planning based on a comprehensive flood risk conceptualization Mitigation Adapt Strateg Glob Change. 2015;20(6):845-864.

30. Sugandi D. A Model Of Environmental Conservation For Sagara Anakan. International Journal Of Conservation Science. 2014;5(1):95-106.

31. Haque MZ, Reza MIH, Rahim SA, et al. Behavioral Change Due To Climate Change Effects Accelerate Tiger Human Conflicts: A Study On Sundarbans Mangrove Forests, Bangladesh. International Journal of Conservation Science. 2015;6(4);669-684.

32. Rushayati SB, Alikodra HS, Dahlan EN, et al. Development of Green Open Space Based on Surface Temperature Distribution in Bandung District. Jurnal Forum Geografi. 2011;25(1):17-26.

33. Bhura CS, Singh NP, Mori PR, et al. Estimation of Surface Run-off For Ahmedabad Urban Area using SCS-CN Method and GIS. International Journal of Science Technology \& Engineering. 2015;1(11):411-416.

34. Duffková R. Evaluation of Management-Dependent Changes in the Water Regime of Extensive Grasslands. Journal of Soil \& Water Resv. 2008;3(1):1-11.

35. Tambunan MP. Kaitan Penggunaan Lahan Perkotaan Dengan Banjir Departemen Geografi, FMIPA Universitas Indonesia. 2007.

36. Guzha AC, Rufino MC, Okoth S, et al. Impacts of land use and land cover change on surface run-off,discharge and low flows: Evidence from East Africa. Journal of Hydrology: Regional Studies. 2018;15:49-67.

37. Sindhu D, Shivakumar BL, Ravikumar AS. Estimation Of Surface Runoff In Nallur Amanikere Watershed Using Scs-Cn Method. IC-RICE Conference. 2013;404-409.

38. Nex F, Delucchi L, Gianelle D, et al. Land Cover Classification and Monitoring: the STEM Open Source Solution. European Journal of Remote Sensing. 2015;48(1):811-831.

39. Jifa AN, Rachmansyah A, Afandhi A. Analysis of Infiltration Well Dimensional in Kedungkandang District, Malang City, Indonesia. Indonesian Journal of Environment and Sustainable Development. 2018;9(1):33-38.

40. Dinas PU, Pengairan. Data Curah Hujan. Bandung Jawa Barat. 2016.

41. Republic. The Gedebage Retention Pool Was Built Starting Mid-Year. 2019. 